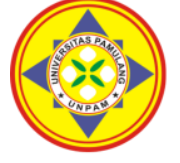

\title{
PENGARUH GREEN MARKETING TERHADAP KEPUTUSAN PEMBELIAN VAPE STUDI PADA PELANGGAN D'MOM CAFE KOTA SORONG
}

\author{
${ }^{1}$ Alfin Lezlo Marley Rumaseb, ${ }^{2 *}$ Retno Dewi Wijiastuti \\ Universitas Muhammadiyah Sorong, Indonesia \\ *retnodewi@um-sorong.ac.id
}

\begin{abstract}
Abstrak
Penelitian ini bertujuan untuk mendeskripsikan bagaimana pengaruh green marketing terhadap keputusan pembelian vape studi pada pelanggan di D'mom cafe kota Sorong. Metode penelitian yang digunakan dalam penelitian ini adalah melalui pendekatan deskriptif, kuantitatif, dengan mengumpulkan informasi melalui observasi, dokumentasi, hingga pelaksanaan wawancara dengan informan penelitian yang terdiri dari para pelanggan pada D'mom cafe kota Sorong.Penelitian mengenai Pengaruh Green Marketing terhadap keputusan pembelian vape studi pada pelanggan D'mom cafe Sorong menghasilkan kesimpulan yang didasarkan pada analisis bahwa Produk Dan Promosi Berpengaruh Terhadap keputusan pembelian vape di D'mom cafe Sorong, Hasil analisis menunjukan Produk dan Promosiberpengaruh secara positif dansignifikan terhadap keputusan pembelian vape di D'mom cafe Sorong.
\end{abstract}

Kata Kunci: Green Marketing, Keputusan Pembelian

\begin{abstract}
This Study aims to describe how the influence of green marketing on vape purchasing decision, studies on customers in the D'mom Cafe, Sorong City. The research method used in this study is through a descriptive, quamtitative approach by gathering information through observation, documentation and conducting interviews with research informants consisting of customers at the Sorong City D'mom Café. Research on the Effect of Green Marketing on study vape purchasing decision on Sorong café D'mom customers yielded conclusion based on the analysis that product and promotion influenced the decision to buy vape at D'mom Cafe Sorong. The result of the analysis showed product and promotion had a positif and significant effect for the vape purchase decision at D'mom cafe Sorong.
\end{abstract}

Keywords: Green Marketing, Purchasing Decision

\section{PENDAHULUAN}

Di Indonesia sendiri, rokok konvensional menjadi penghasil pajak terbesar, artinya meski berbahaya untuk kesehatan, tetapi perusahaan rokok tetap berjalan dan memproduksi rokok. Cukup sulit menutup perusahaan tersebut, karena faktor lain selain pajak yang berguna untuk negara kita, yakni lowongan pekerjaan, dan juga para petani tembakau yang masuk kategori masyarakat kecil. Berbeda dengan vape, dimana yang akan dikenakan be cukai pada tanggal 1 oktober 2018, vape masih laris diproduksi hingga di Sorong papua. Berbeda juga dengan satu bungkus rokok yang harganya kisaran Rp. 18.000 - Rp. 25.000, vape lebih mahal, dengan alat nya kisaran harga Rp. 300.000 - Rp. 2.000.000. tapi pemasaran vape masih berjalan dikarenakan, vape sudah menjadi gaya hidup sehari-hari atau life style, ada komunitasnya, dan belum $100 \%$ berbahaya. Peneliti akan meneliti Di D'mom Cafe jalan kilang kilo meter 9,5 Kota Sorong tentang pengaruh green marketing terhadap keputusan pembelian rokok elektrik (vape).Peneliti mengambil judul ini karena Cafe adalah tempat masyarakat bersantai dengan keluarga, teman, kerabat, dan sebagainya untuk makan dan minum.Akan tetapi, cafe ini menyediakan tempat khusus vape lounge, dimana orang bisa mengonsumsi vape dan mengeluarkan uap yang tebal, dimana kita ketahui cafe tersebut tempat makan.Hal ini dikarenakan 
banyak juga pelanggan yang memakai vape.

Berdasarkan konteks green marketing yang telah diuraikan diatas, peneliti ingin mengetahui bagaimanakah sesungguhnya penilaian konsumen akan produk vape yang memperhatikan aspek lingkungan bila dipandang dari bauran pemasarannya. Akan dicoba dievaluasi secara empiris hubungan antara Green Marketing dengan Penggunaan Vape.

\section{TINJAUAN PUSTAKA}

1. Manajemen Pemasaran

Menurut Kotler (2000:9) adalah Proses perencanaan dan pelaksanaan pemikiran, penetapan harga, promosi serta penyaluran gagasan, barang dan jasa, untuk menciptakan pertukaran yang memenuhi sasaran-sasaran individu dan organisasi.

2. Vape (Rokok Elektrik)

Vape atau biasa disebut rokok elektrik adalah sebuah inovasi dari bentuk rokok konvensional menjadi rokok moderen, yang diciptakan pertama kali oleh Hon Lik pada tahun 2003. Selain itu, vape lebih hemat dari pada rokok biasa karena bisa diisi ulang dengan cairan yang bernama Liquid. Proses pembakaran vape hanya menggunakan batu baterai, untuk membantu menghasilkan energi listrik kepada alat vape, dan memanaskan kapas yang terlilit oleh kantal ( kawat yang dililit), yang akan menghasilkan uap untuk dihisap layaknya rokok konvensional biasa.

3. Lifestyle (Gaya Hidup )

Menurut Minor dan Mowen (2002), gaya hidup adalah menunjukan bagaimana orang hidup bagaimana membelanjakan uangnya, dan bagaimana mengalokasikan waktu

4. Keputusan Pembelian

Menurut Follet (dalam Hasan, 2002), merupakan hasil dari pemecahan masalah yang sedang dihadapimya dengan tegas.Suatu keputusan merupakan jawaban yang pasti terhadap suatu pertanyaan.
5. Green Marketing ( Pemasaran Hijau )

Menurut Dahlstorm (2010:6) green marketing adalah proses perencanaan dan pelaksanaan bauran pemasaran untuk memfasilitasi konsumsi, produksi, distribusi, promosi, kemasan dan produk reklamasi dengan cara yang sensitif atau responsif terhadap kepentingan ekologi.

6. Produk

Menurut Al-Bakry (2007) Yaitu produk yang dapat memenuhi keinginan dan kebutuhan konsumen namun tidak melanggar aturan-aturan tentang lingkungan.

7. Promosi

Menurut Jerome Mc. Charty yang dikutip oleh Kotler dan Armstrong (2014:76) adalah aktifitas yang digunakan untuk mengkomunikasikan informasi mengenai produk yang akan dijual kepada konsumen potensial.

\section{METODE}

Penelitian ini dilakukan di D'mom Cafe Kota Sorong.Penelitian ini dilaksanakan pada bulan November 2018 sampai selesai. Populasi dalam penelitian ini adalah pelanggan D'mom cafe, dan sampel penelitian ini adalah 40 responden yang datang pada D'mom café. Peneliti menggunakan jenis data Kuantitatif dimana kumpulan data berupa angka. peneliti terbagi menjadi dua bagian yaitu: Primer dan Sekunder Peneliti menggunakan teknik pengumpulan data berupa Wawancara Kuesioner Observasi

\section{HASIL DAN PEMBAHASAN}

1. Pembahasan Hasil Penelitian

a. Pengaruh produk terhadap keputusan pembelian vape di D'mom cafe Sorong.

Berdasarkan pengolahan data menggunakan regresi berganda dengan membandingkan nilai signifikan yang harus lebih kecil dari $0,05(0,000>0,05)$ dan nilai t hitung yang harus lebih besar dari $t$ tabel $(0,4,492>(2,02619)$ maka produk berpengaruh positif dan tidak 
signifikan terhadap keputusan pembelian, begitu juga dengan menggunakan korelasi produk memiliki pengaruh terhadap keputusan pembelian vape di D'mom cafe Sorong.

b. Pengaruh promosi terhadap keputusan pembelian vape di D'mom cafe Sorong.

Berdasarkan pengolahan data menggunakan regresi berganda dengan membandingkan nilai signifikan yang harus lebih kecil dari $0,05(0,000>0,05)$ dan nilai t hitung yang harus lebih besar dari t tabel $(0,4,934>(2,02619)$ maka promosi berpengaruh positif dan tidak signifikan terhadap keputusan pembelian, begitu juga dengan menggunakan korelasi promosi memiliki pengaruh terhadap keputusan pembelian vape di D'mom cafe Sorong.

\section{PENUTUP}

\section{Kesimpulan}

Berdasarkan uraian pada bab-bab sebelumnya, dan dari hasil analisis serta pembahasan dapat diambil kesimpulan sebagai berikut :

1. Dari uji regresi yang dilakukan dapat disimpulkan bahwa produk berpengaruh terhadap keputusan pembelian vape di D'mom cafe Sorong. Hasil pengolahan dengan SPSS versi 20 diperoleh nilai $t_{\text {hitung }}(0,4,492)$ lebih besar $t_{\text {tabel }}(2,02619)$ dan nilai signifikan 0,000lebih besar dari 0,05 yang berarti bahwa terdapat pengaruh yang positif dan signifikan antara variabel produk terhadap keputusan pembelian vape di D'mom cafe Sorong.

2. Dari uji regresi yang dilakukan dapat disimpulkan bahwa promosi berpengaruh terhadap keputusan pembelian vape di D'mom cafe Sorong. Hasil pengolahan dengan SPSS versi 20 diperoleh nilai $t_{\text {hitung }}(0,4,934)$ lebih besar dari $t_{\text {tabel }}(2,02619)$ dan nilai signifikan 0,000 lebih besar dari 0,05 yang berarti bahwa terdapat pengaruh yang positif dan signifikan antara variabel promosi terhadap keputusan pembelian vape di D'mom cafe Sorong.

3. Penelitian mengenai Pengaruh Green Marketing terhadap keputusan pembelian vape studi pada pelanggan D'mom cafe Sorong menghasilkan kesimpulan yang didasarkan pada analisis bahwa Produk Dan Promosi Berpengaruh Terhadap keputusan pembelian vape di D'mom cafe Sorong, Hasil analisis menunjukan Produk dan Promosiberpengaruh secara positif terhadap keputusan pembelian vape di D'mom cafe Sorong

\section{Saran}

Berbagai kegiatan yang dilakukan baik dari menganalisa sampai dengan menguraikan kesimpulan maka penulis mencoba memberikan saran sebagai bahan evaluasi untuk perusahaan sendiri. Sebagai berikut :

1. Mengingat variabel yang paling tinggi mempengaruhi keputusan pembelian vape di D'mom cafe Sorong adalah Promosi, Maka sebaiknya perusahaan lebih memperhatikan tingkat promosi penjualan dan periklanan, Karena semakin tinggi tingkat promosi penjualan dan periklanan maka Semakin tinggi pula omset penjualan produk vape Pada D'mom cafe .

2. Penulis berharap ada penelitian berikutnya mengenai keputusan pembelian diluar Variabel produk dan promosi, Karena masih banyak variabelvariabel lain yang akan berpengaruh lebih besar terhadap keputusan pembelian serta jauh lebih menarik lagi untuk dibahas dan dilakukan sebuah penelitian.

\section{DAFTAR PUSTAKA}

Almuarief. Pengaruh Green Marketing Terhadap Minat Beli Yang Dimediasi Oleh Brand Image ( Studi Pada Air Minum Dalam Kemasan Ades ),Yogyakarta.2016

Armstrong, Product means the good and services combination the company 
offers to the target market. Evanston Illionis: Northwestern University, 2000.

Dharmmesta, Basu Swastha. Manajemen Pemasaran. Sorong: Universitas Terbuka, 2011

Haque, M. G., Nurjaya, N., Affandi, A., Erlangga, H., \& Sunarsi, D. (2021). Micro Financial Sharia Non-bank Strategic Analysis: a Study at BMT Beringharjo, Yogyakarta. Budapest International Research and Critics Institute (BIRCI-Journal): Humanities and Social Sciences, 4(2), 1677-1686.

Kotler, Philip. Manajemen Pemasaran edisi milenium. Evanston Illionis: Northwestern University, 2000.

Kotler, Philip. Promotion refers to activities that communicate the merits of the product and persuade target customers to buy it. Evanston Illionis: Northwestern University, 2000.

Laksana, Fajar. Manajemen Pemasaran pendekatan praktis. Yogyakarta: Graha Ilmu, 2008.

Nurjaya, N., Sunarsi, D., Effendy, A. A., Teriyan, A., \& Gunartin, G. (2021). Pengaruh Etos Kerja Dan Disiplin Kerja Terhadap Kinerja Pegawai Pada Dinas Kehutanan Dan Perkebunan Kota Bogor. JENIUS (Jurnal Ilmiah Manajemen Sumber Daya Manusia), 4(2), 172-184.

Oktavia, Umi. Analisis Pengaruh Green Marketing Terhadap Keputusan Pembelian Konsumen Produk PT.Unilever Tbk. Surakarta: Universitas Muhammadiyah Surakarta 2013. Palwa, Ariyanto. Pengaruh Green Marketing Terhadap
Keputusan Pembelian Yang dimediasi minat beli (studi pada pelanggan the body shop diplaza ambarukmo,Yogyakarta. 2014.

Prothero, Fitchett. Journal of Macromarketing England, 2000.https:/ / eprints.uny.ac.id/8757/ 5/LAMPIRAN\%20-10408145002.pdf

Purwanti, Y. (2021). The Influence Of Digital Marketing \& Innovasion On The School Performance. Turkish Journal of Computer and Mathematics Education (TURCOMAT), 12(7), 118-127.

Rasyid, N., \& Rawi, R. D. P. (2018). Pengaruh Bauran Pemasaran Terhadap Penjualan Pada Pt. Nestle Indofood Citarasa Indonesia Di Makassar. Sentralisasi, 7(2), 11-27.

Rawi, R. D. P., \& Lewenussa, R. (2019). Pengaruh Karakteristik Dan Kinerja Generation Young (Gen Y) Terhadap Ekspektasi Peluang Bisnis (Studi Kasus Di PT. Adira Group Kota Sorong). Gorontalo Management Research, 2(2), 80-89.

Sugiyono, teknik pengambilan populasi dan sampel metodologi penelitian,Kuningan, 2015, http:// repository.unpas.ac.id/30085 /7/7/\%20BAB\%200III.pdf

Sunyoto, Danang. Teori, Kuesioner dan Analisis Data Untuk Pemasaran dan Perilaku Konsumen. Yogyakarta: Graha Ilmu, 2013.

Wangsi, M. M., \& Rawi, R. D. P. (2018). Perlindungan Konsumen Dalam Pelabelan Produk Menurut Ekonomi Islam. Sentralisasi, 7(1), 1-9. 